\title{
Composite chest wall reconstruction using titanium plates and mesh preserves chest wall function
}

\author{
Teodorico Iarussi, MD, Alessandro Pardolesi, MD, Pierpaolo Camplese, MD, and Rocco Sacco, MD, \\ Chieti, Italy
}

\begin{abstract}
Although multiple techniques have been used to correct chest wall defect, the impact of these on chest wall function (chest wall mechanism/pulmonary function) is poorly studied. ${ }^{1}$ In our experience, composite chest wall reconstruction using titanium plates and mesh correct both the cosmetic and physiologic abnormalities. ${ }^{2-4}$
\end{abstract}

\section{TECHNIQUE}

Surgical reconstruction was performed in 13 patients using a Titanium Fixation System (Synthes, West Chester, Pa); Figure 1, A, consisting of titanium plates and self-tapping unlock screws. All plates can be joined by U-shaped release pins, which allows quick and easy surgical access in case of reoperations.

There were 3 patients groups (Table 1). In groups A and $\mathrm{B}$, rib reconstruction was performed with titanium plates and a dual-mesh patch was placed and fixed to the plates to avoid direct contact between prosthesis and lung parenchyma (Figure 1, $B$ ).

In group $\mathrm{C}$, the first patient, in particular, received an en bloc sternectomy for sternum infection after cardiac surgery, and then 4 titanium plates were fixed to the clavicle and to both sides of the second, fourth, and fifth rib, respectively, successively covered with a titanium patch. ${ }^{5}$

In all cases of sternum resection, a bilateral pectoralis major muscle flap was carried out to cover the prosthesis.

There was no postoperative mortality. A subcutaneous seroma occurred in 2 patients and atrial fibrillation and prolonged air leakage in 1 patient. A 3-day stay in the intensive care unit was required for hemodynamic instability in a patient with malignant mesothelioma having extrapleural pneumonectomy and chest resection. All the other patients were extubated immediately at the end of the surgical procedures. Pre- and postoperative data showed a good preservation of respiratory function even after lung resection if compared with predictive values (Table 1).

From the U.O. Clinica Chirurgica School of Specialization of Thoracic Surgery, University Hospital Via dei Vestini, Chieti, Italy

Received for publication May 20, 2009; revisions received June 15, 2009; accepted for publication July 13, 2009; available ahead of print Sept 10, 2009.

Address for reprints: Teodorico Iarussi, MD, Via dei Maruccini 5, 65127 Pescara, Italy (E-mail: teddyiarussi@hotmail.com).

J Thorac Cardiovasc Surg 2010;140:476-7

$0022-5223 / \$ 36.00$

Copyright (c) 2010 by The American Association for Thoracic Surgery doi: $10.1016 /$ j.jtcvs.2009.07.030
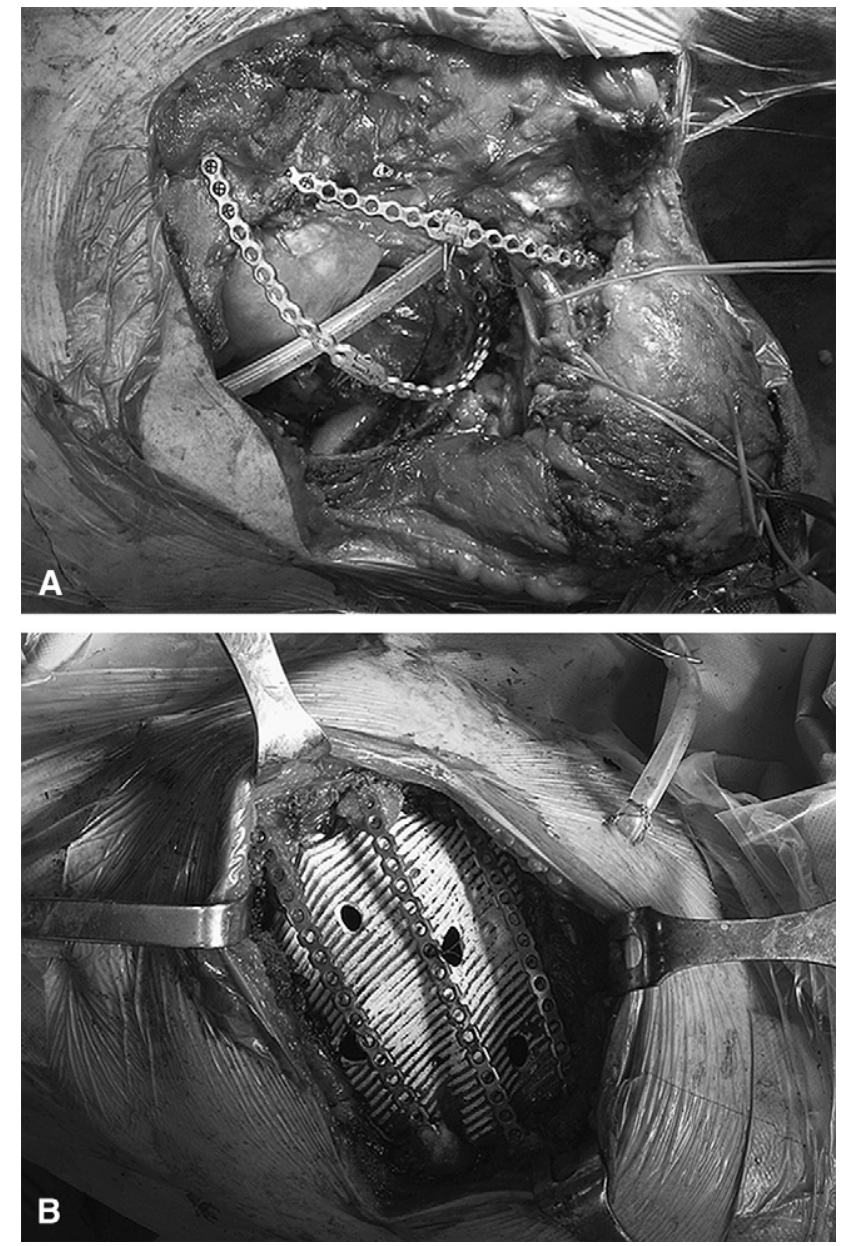

FIGURE 1. A, Left clavicle and first rib reconstruction; B, rib reconstruction with titanium plates and a dual-mesh patch.

\section{DISCUSSION}

The reported technique leads to chest wall stability and physiologic mobility preservation, allowing quick patient mobilization and participation in respiratory rehabilitation programs. Plates can be easily shaped to replace removed ribs, even in cases of bad bone quality. In cases of large chest wall defect, stability can be obtained without rebuilding each rib removed. In cases of removal of 3 or 4 ribs, for example, chest cage stability can be obtained with reconstruction of 2 ribs. Data from our experience, even if consisting of few cases, support the practical utility of titanium plate application for rib and sternal reconstruction. 
TABLE 1. Personal observation

\begin{tabular}{|c|c|c|c|c|c|}
\hline Patient (age) & Diagnosis & Surgical treatment & Surgical reconstruction & Preoperative FEV $_{1}(\mathrm{~L})$ & 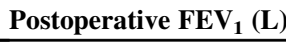 \\
\hline \multicolumn{6}{|l|}{ Group A } \\
\hline $1(47 \mathrm{y})$ & Sarcoma & V, VI, VII & $\mathrm{V}, \mathrm{VI}$ & 2.67 & $2.80(+4.8 \%)$ \\
\hline $2(82 y)$ & Sarcoma & V, VI, VII & $\mathrm{V}, \mathrm{VI}$ & 2.96 & $2.78(-6.1 \%)$ \\
\hline $3(56 y)$ & Metastasis from sarcoma & $\mathrm{V}, \mathrm{VI}$ & $\mathrm{V}$ & 1.31 & $1.25(-4.5 \%)$ \\
\hline $4(58 \mathrm{y})$ & Trauma & VI, VII & VI, VII & 2.10 & $1.99(-5.2 \%)$ \\
\hline $5(71 \mathrm{y})$ & Trauma & IV, V, VI & IV, VI & 1.64 & $1.65(+0.6 \%)$ \\
\hline \multicolumn{6}{|l|}{ Group B } \\
\hline $6(54 y)$ & NSCLC & $\begin{array}{l}\text { Upper lobectomy } \\
\text { (III, IV, V) }\end{array}$ & III, V & 2.49 & $1.97(-20.9 \%)$ \\
\hline $7(48 \mathrm{y})$ & NSCLC & $\begin{array}{l}\text { Upper lobectomy } \\
\text { (III, IV, V) }\end{array}$ & III, V & 2.80 & $1.71(-38.9 \%)$ \\
\hline $8(64 y)$ & NSCLC & (clavicle, I, II, III) & Clavicle, II & 1.42 & $0.98(-30.9 \%)$ \\
\hline $9(56 \mathrm{y})$ & $\begin{array}{c}\text { Malignant pleural } \\
\text { mesothelioma }\end{array}$ & $\begin{array}{l}\text { Left extrapleural } \\
\text { pneumonectomy } \\
\text { (II, III, IV, V, VI) }\end{array}$ & III, IV, VI & 2.61 & $1.36(-47.8 \%)$ \\
\hline \multicolumn{6}{|l|}{ Group C } \\
\hline $10(65 \mathrm{y})$ & Infection & Total sternectomy & Manubrium and sternum & 1.49 & $1.55(-4.0 \%)$ \\
\hline $11(48 \mathrm{y})$ & Renal metastasis & Subtotal sternectomy & Sternum & - & - \\
\hline $12(49 y)$ & Fracture & Partial sternectomy & Sternum & 2.98 & $2.89(-3.0 \%)$ \\
\hline $13(69 y)$ & Fracture & Osteosynthesis & Sternum & - & - \\
\hline
\end{tabular}

Group A, Rib resection; group B, lung and rib resection; group $C$, sternal resection; $N S L C$, non-small cell lung cancer; $F E V_{l}$, forced expiratory volume in 1 second.

\section{References}

1. Bibas BJ, Bibas RA. Operative stabilization of flail chest using a prosthetic mesh and methylmethacrylate. Eur J Cardiothorac Surg. 2006;29:1064-6.

2. Cicilioni OJ Jr, Stieg FH 3rd, Papaniculaou G. Sternal wound reconstruction with transverse plate fixation. Plast Reconstr Surg. 2005;115:1297-303.

3. Voss B, Bauernschmitt R, Will A, et al. Sternal reconstruction with titanium plates in complicated sternal dehiscence. Eur J Cardiothorac Surg. 2008;34:139-45.
4. Lee TY, Estrera AL, Safi HJ, Khalil KG. Total sternal reconstruction using a titanium plate-supported methyl methacrylate sandwich. Ann Thorac Surg. 2007;84: 664-6.

5. Iarussi T, Marolla A, Pardolesi A, Patea RL, Camplese P, Sacco R. Sternectomy and sternum reconstruction for infection after cardiac surgery. Ann Thorac Surg. 2008;86:1680-1.

\section{Transcatheter valve replacement: Resection and valved stent implantation in a beating heart}

René Hubert Bombien, MD, ${ }^{\mathrm{a}}$ Lucian Lozonschi, MD, ${ }^{\mathrm{b}}$ Jochen Cremer, MD, PhD, ${ }^{\mathrm{a}}$ and Georg Lutter, MD, $\mathrm{PhD},{ }^{\mathrm{a}}$ Kiel, Germany, and Madison, Wis

During the past 10 years, different models for the transcatheter removal of heart valves have been evaluated. The experiments were performed in different in vitro or in vivo

\footnotetext{
From the Department of Cardiovascular Surgery, ${ }^{a}$ University Hospital SchleswigHolstein, Campus Kiel, Kiel, Germany; and Division of Cardiothoracic Surgery, ${ }^{b}$ University of Wisconsin School of Medicine, Madison, Wis.

Disclosures: None.

Received for publication Nov 2, 2009; accepted for publication Jan 1, 2010; available ahead of print March 26, 2010.

Address for reprints: René Hubert Bombien, MD, Department of Cardiovascular Surgery, University Hospital Schleswig-Holstein, Campus Kiel, Arnold-Heller-Strasse 7, D-24105 Kiel, Germany (E-mail: rbombien@quabo.de).

J Thorac Cardiovasc Surg 2010;140:477-9

$0022-5223 / \$ 36.00$

Copyright (c) 2010 by The American Association for Thoracic Surgery

doi:10.1016/j.jtcvs.2010.01.006
}

models. ${ }^{1-3}$ This report describes a model for complete heart valve replacement with resection before valved stent implantation in a beating heart.

\section{CLINICAL SUMMARY}

The pulmonary valve isolation chamber (PVIC) system was developed to generate an isolated chamber avoiding the escape of debris during the resection process. The system (length, $160 \mathrm{~mm}$;, $30 \mathrm{~F}$ ) consists of 2 balloons: a subvalvular balloon and a supravalvular balloon in the pulmonary artery (Figure 1, $A$ ). The pressures of the balloons were monitored to prevent pressure decreases caused by leakiness. To ensure a clear view during the process, an irrigation flow was established. 